\title{
JEJAK MARXISME DI INDONESIA
}

\author{
A. Syatori \\ IAIN Syekh Nurjati Cirebon
}

\begin{abstract}
Abstrak: Pada akhir abad ke-19 paham liberalisme ekonomi ala Barat terdengar gaungnya oleh pemerinah Hindia-Belanda. Paham itu mengubah kebijakan ekonomi pemerintah dari yang semula kerja paksa menjadi industrialisasi. Masuknya investasi swasta telah mengubah tanah-tanah perkebunan menjadi pabrik-pabrik dan mengubah buruh-buruh tani bumi putra menjadi buruh-buruh pabrik. Kebijakan pemerintah itu mendapat kritik dari kaum kiri yang berpaham Marxisme di Belanda. Kritik itu berhasil mendesak pemerintah untuk memberlakukan kebijakan politik 'balas-budi' atau eticshe politic. Kebijakan ini lah yang kemudian menjadi awal masuknya paham Marxisme di Indonesia. Kebijakan politik etis telah membuka kran terbentuknya perkumpulan-perkumpulan di HindiaBelanda. Sneevliet, seorang anggota kaum kiri Belanda masuk di Indonesia membawa paham Marxisme dengan mendirikan Indische Social Democratische Vereniging (ISDV). Pengaruh ISDV sampai pada Sarekat Islam (SI) yang saat itu memiliki basis massa yang banyak, yang kemudian membentuk SI-Merah. Oleh perkumpulan ini Marxisme menemukan kesamaan dengan ajaran Islam. Keduanya bertemu pada kesamaan pada perjuangan pembebasan kaum lemah. Analisis perjuangan kelas dalam Marxisme digunakan untuk menginterpretasi ayat-ayat alQur'an. Misalnya, Hadji Misbach menafsirkan surat al-Humazah menemukan dua kontradiksi kelas, antara kaum uang dan kaum mustadl'afin yang disebabkan oleh fitnah kapitalisme berupa kesengsaraan rakyat. Selain itu Marxisme juga memengaruhi pemikiran tradisi Jawa, yang memunculkan semboyan 'Sama Rata-Sama Rasa' dan 'Bangkitnya Kaum Kromo'. Dua semboyan ini bertemu pada gagasan Marx tentang "masyarakat tanpa kelas" yang tertuang dalam Babad Tanah Jawa-nya Marco Kartodikromo. Paham ini melahirkan para pejuang revolusi di Hindia-Belanda. Mereka menyebarkan gagasan Marxisme dan melakukan aksi-aksi pengorganisasian rakyat, terutama pada kelompok buruh pabrik. Perjuangan itu telah sampai pada pembentukan organisasi revolusioner yang bernama Partai Komunis Indonesia (PKI).
\end{abstract}

Kata kunci: marxisme, kapitalisme, imperialisme, ISDV, PKI. 
“ Selamannja saja hidoep, selamannja saja akan berichtiar menjerahkan djiwa saja goena keperloean ra'jat. Boeat orang jang merasa perboetannja baik goena sesama manoesia, boeat orang seperti itoe, tiada ada maksoed takloek dan teroes tetap menerangkan ichtiarnja mentjapai maksoednja jaitoe Hindia merdika dan slamat sama rata sama kaja semoea ra'jat Hindia “"

( Semaoen, 24 Djoeli 1919)

Mulai paruh terakhir abad ke-19, pemerintah kolonial di Hindia Belanda secara perlahan mulai menampakkan pergeseran dalam kebijakan. Sistem jajahan ala VOC berubah menjadi sebuah jajahan bersistem liberal. Perkebunan yang dulunya dimonopoli pemetintah, kini boleh dikelola oleh modal-modal swasta, sistem kerja paksa dan rodi dihapuskan dan diganti dengan sistem kerja upah secara bebas. Hal ini terutama berkaitan dengan semakin santernya arus kritik terhadap orientasi kebijakan terhadap komunitas tanah jajahan. Kritik mengarah kepada gugatan atas kebijakan kolonial yang eksploitatif dan menindas. Pendudukan yang imperialistik ini bagi kaum kiri Belanda -yang pada saat itu semakin berkibar- hanya memberikan keuntungan sepihak melalui eksploitasi dan pengurasan sumber alam. Singkatnya, tekanan bertubi-tubi kaum kiri Belanda telah mendesak pemerintah melakukan kompromi-kompromi. Sebagai hasilnya, muncullah gagasan politik "balas budi" atau disebut juga etische politic. Jadi, statemen-statemen bahwa politik etis merupakan "political will" pemerintah kolonial adalah omong kosong belaka. Kemunculannya lebih disebabkan karena keterdesakan-keterdesakan akibat oposisi sayap kiri. ${ }^{1}$

Politik etis setidaknya mengusung tiga isu sentral : perbaikan pendidikan, irigasi dan kependudukan. Dalam praktik, kebijakan ini terwujud dalam pendirian sekolah-sekolah ongko loro dan ongko siji. Juga, sikap yang lebih toleran atas terbentuknya perkumpulanperkumpulan, baik berdasarkan politik maupun keagamaan. Keterbentukan Budi Oetomo (BO), Indische Partij (IP), Sarekat Islam (SI) dan organisasi lain adalah buah dari etische politic ini. Dalam relasi

M. Zaki Mubarak, "Marxisme-Religius, Pemikiran dan Revolusi Dalam SI-Merah Solo”, Gerbang edisi 02 tahun II April-Juni 1999. hlm 55. 
kapital, isi dari etische politic ini menuntut dilakukannya perubahan kebijakan, utamanya dalam tata aturan perburuhan. Terutama yang paling ekstrim menghendaki perubahan radikal pemilikan alat-alat produksi. Alat-alat produksi semestinya dikuasai kaum buruh (proletar). Tuntutan ini sama sekali ditolak oleh kelompok "kubu liberal" atau sayap kanan yang berkeras mempertahankan kepentingannya atas keselamatan modal mereka meski dengan cara-cara eksploitasi. Gelombang liberalisme ekonomi Barat mulai melanda Hindia Belanda. Investasi begitu terbuka luas bagi kelompok-kelompok non pemerintah. Bak disulap, dalam sejurus, kota-kota mulai dipenuhi oleh pabrik-pabrik, jaringan infrastruktur transportasi jalan raya dan rel-rel mulai dibentangkan sepanjang Jawa dan Sumatera. Selanjutnya, migrasi dari desa ke kota semaki meningkat. Menjadi buruh dipabrik menjadi profesi baru, sebuah identitas lebih bergengsi dibanding buruh tani di pedesaan. Maka mulailah muncul hierarki baru akibat relasi-relasi produksi ini, yakni kaum buruh (proletar) dan majikan pemilik alat produksi (kapitalis). Kesinambungan ekonomis kaum buruh semakin tergantung oleh sistem relasi-relasi kerja ini. Aksi-aksi protes dan mogok buruh mulai umum terjadi disebabkan relasi yang tidak adil.

\section{Indonesia "Berkenalan" Dengan Marxisme}

Ketika Hindia Belanda berada dalam kepungan liberalisme ekonomi-politik, pada tahun 1913, seorang pemimpin buruh dan anggota Sociaal Democratische Arbeiders Partij (SDAP) atau Partai Buruh Sosial Demokrat Belanda bernama Sneevliet ${ }^{2}$ datang ke Hindia Belanda (Indonesia). Pada masa-masa awal keberadaannya di Hindia Belanda, ia bekerja sebagai staff redaksi pada surat kabar soerabajaasch Handelsblad Surabaya. Lalu ia pindah ke Semarang disusul dengan kedatangan Adolf Baars dan Peter Bergsma, ${ }^{3}$ dua kawan seperjuangannya. Di Semarang,

2 Nama lengkapnya adalah Hendricus Josephus Franciscus Marie Sneevliet, lahir di Rotterdam, 13 Mei 1883. sejak tahun 1902, ia melibatkan diri dalam kehidupan partai politik dan bergabung dengan Sociaal Democratische Arbeiders Partij (SDAP) sampai tahun 1909. Lihat Soegiri DS. dan Edi Cahyono, Gerakan Serikat Buruh, Jaman Kolonial Hindia Belanda Hingga Orde Baru, Jakarta:Hasta Mitra, 2003. hlm 121. Lihat juga Soe Hok Gie, Di Bawah Lentera Merah, Riwayat Sarekat Islam Semarang 1917-1920, Ygyakarta:Bentang, 2005. hlm 89.

3 Tentang karakter, latarbelakang dan kecenderungan politik ketiga tokoh Marxis Belanda itu dapat diketahui dalam DMG Koch, Menudju Kemerdekaan, Djakarta:Dj. 
bersama kedua kawannya tersebut ia bergabung dengan Vereniging Voor Spoor-en Tramweg Personeel (VSTP), serikat buruh (kereta api) tertua di Indonesia. Satu tahun kemudian, tepatnya pada tanggal 09 Mei 1914, bersama kawan-kawan sosialis lainnya, seperti J.A. Bransteder dan H.W. Dekker, mereka mendirikan Indische Social Democratische Vereniging (ISDV). Setahun berikutnya ISDV menerbitkan majalah Het Vrije Woord dengan redaksi Sneevliet, Bergsma dan Adolf Baars. Melalui organ-organ inilah benih-benih marxisme mulai ditanamkan di bumi Hindia Belanda.

Seiring dengan manifesto Lenin kepada Komintern (Komunis Internasional) untuk melakukan "infiltrasi" ke dalam komponenkomponen kekuatan sosial, politik, ekonomi, pendidikan dan kebudayaan, ISDV mulai menebar pengaruhnya kepada kelompok-kelompok pergerakan bumiputera yang telah memiliki pengaruh besar dalam pergerakan nasional Indonesia. Perhatian pun tertuju pada Sarekat Islam (SI) yang pada saat itu telah memiliki basis massa yang cukup kuat. Hanya dengan beberapa 'jurus', angkatan muda SI berada dibawah pengaruh ISDV, baik yang ada di Semarang (Semaoen, Darsono dll), Jakarta (Alimin dan Musso), Solo (H. Misbach), Salatiga (Marco Kartodikromo) maupun dikota-kota lainnya. Lewat tangan-tangan kaum muda yang potensial ini, pelan namun pasti, SI yang semula merupakan organisasi "biasa-biasa saja" mulai beranjak ke arah yang lebih radikal dan bercorak sosialis-revolusioner. Ini terutama ditunjukkan oleh SI cabang Semarang pimpinan Semaoen, SI cabang Solo pimpinan H. Misbach dan SI cabang Salatiga pimpinan Marco Kartodikromo. Mereka inilah yang dibelakang hari populer dengan sebutan kelompok SI-Merah.

Sebagaimana yang dititahkan oleh para petinggi ISDV, "SIradikal" mulai 'belajar' melakukan pembacaan atas realitas sosial-politik di Hindia Belanda dengan menggunakan analisis Marxistis. Mereka berpendapat bahwa penyebab kesengsaraan dan petaka bagi rakyat Indonesia adalah akibat struktur kemasyarakatan yang ada, yakni struktur masyarakat tanah jajahan yang diperas dan ditindas oleh kaum kapitalis, atau dalam istilah mereka disebut dengan 'kaoem oewang'. Seperti kaum sosialis lainnya, mereka menjadikan kapitalisme sebagai seteru utama, disamping imperialisme dan kolonialisme. Kapitalisme dituding sebagai

Pembangunan, 1951 dan Ruth T McVey, The Rise of Indonesian Communism, IthacaNY:Cornell UP 1965. 
sumber dari segala macam krisis kemanusiaan dan ketertindasan yang dialami oleh rakyat Hindia Belanda (Indonesia). Kondisi memprihatinkan yang diderita bangsa Hindia Belanda digambarkan, “...di kampoengkampoeng, di desa dan di djalan-djalan besar, kelihatanlah olih mata kita, beberapa orang Hindia Belanda jang woedjoednja terlaloe menjedihkan hati, berpakaian robek-robek, badan koeroes-koeroes dan bergelandangan kijan kemari oenteok mentjari makan, reomah mereka jang isinja tjoema kendil koewali dari tanah itoe hampir roentoeh dan banjak ketirisan. ${ }^{4}$ Seorang penulis yang mengaku bernama Botjah Goenoengkidoel dengan begitu lugas menggambarkan kebusukan kapitalisme dan imperialisme di surat kabar SI Yogyakarta, Doenia Baroe, pimpinan Soerjopranoto. “ Lain dari pada itoe, ada poela orang - orang jang toeroen deradjat kemanoesiaannja, jaitoe orang jang selaloe menoeroeti hawa nafsoenja mereka pada kekajaan jang sebanjak-banjaknja dan kehormatan jang setinggi-tingginja, sehingga sampai hati menindas dan memeras siapapoen djoega. Nafsoe inilah jang biasa kita seboet kapitalisme dan imperialisme". 5 Dan mereka menyebutkan kejahatan kapitalisme sebagai, “...jang koewat menindas, memeras dan mereboet penghidoepan manoesia jang lainnja. Manoesia jang lemah, jang ditindas, jang diperas, jang dipidjit (tekan) itoe menjadi sengsara, kaloet dan roesak semoeannja, sebab keperloean hidupnja itoe diangkoet, diambil, dirampas dalam tangannja mereka itoe (capitalist). Kesengsaraan makin hari makin bertambah poela. Dimana-mana tempat kedengaran keloeh kesah jang haibat karena ketimpa kemlaratan, kemiskinan, kelaparan ...hadoehhh...beginilah rasa kesengsaraan". 6

Kaum kiri muslim mulai meninggalkan kategorisasi-kategorisasi lama yang memilah pertentangan berlandaskan kaum muslim melawan kaum kafir (non-muslim) dan menggantinya dengan menggunakan analisis kategoris kelas bahwa permusuhan yang telah mengakibatkan semua krisis kemanusiaan berupa ketertindasan, kemelaratan dan kesengsaraan adalah antara kaum mustad'afin (proletar) melawan kaum borjuis-kapitalis (mustakbirin). H. Misbah dengan lantang menyuarakan bahwa perjuangan melawan kapitalisme adalah sesuai dengan spirit pembebasan Islam,

$4 \quad$ Medan Moeslimin 9 (1923). hlm 275.

5 Botjah Goenoengkidoel, Rasa Kemanoesiaan Haroes Hidoep pada kita, dalam Doenia Baroe, Rebo, 11 Djoeli 1923.

6 Medan Moeslimin 10 (1924). hlm 205. 
karena hal yang serupa juga pernah dilakukan oleh Nabi Muhammad SAW. saat melawan 'Kapitalisme Quraisy'. Katanya : "Nabi Moehammad termasoek golongan proletar atawa kaoem boereoh dan Rosoel Moehammad adalah diktatornja organitatie Kaoem Communisten. ${ }^{7}$

Bahkan mereka mengecam 'kaoem oewang' dengan menggunakan ayat-ayat al-Qur'an yang diinterpretasikan dengan cara pandang praksisrevolusioner. Di tangan mereka, pembacaan dan sekaligus pemaknaan alQur'an menjadi bernuansa populis. Korpus suci yang biasanya dititik 'netral' itu, kemudian beralih pendulum menjadi korpus yang radikal. AlQur'an menjadi susunan teks-teks yang berkekuatan dan mengayunkan 'tendangan' ke arah kejahatan kapitalisme. Dengan cara demikian, tampaknya mereka hendak mencoba untuk melihat komunisme dan agama (Islam) dalam titik pandang tidak konvensional. Membaca dan menginterpretasi teks-teks korpus al-Qur'an melalui cara pandang yang Marxian, di satu sisi. Dan di sisi lain, mereka menggunakan perspektif profetis-religius dalam memaknai manifesto Karl Marx. Akibatnya, kaum kiri muslim ini menemukan 'Marx' dalam Qur'an dan menjumpai 'Muhammad' hidup di dalam firman-firman Komunisme. Inilah apa yang dikatakan sebagai "Marxisme-religius".

Pembacaan dan pemaknaan al-Qur'an ala Marxis, terutama terlihat ketika mereka menafsiri surat Al-Humazah sebagai berikut : Al-Humazah, ayat:..."(2)alladzi djama'a malan wa'addadah, tafsir:orang - orang jang mengoempoelkan harta benda (kaoem oewang)...(3) jahsaboe-anna malahoe ahladah, tafsir: ia mengira bahoewa harta bendanja akan kekal...(4) kalla lajoem badzanna filhoethomah, tafsir: segala sangka kaoem oewang/capitalist itoe dibalas, tidak benar sangka-sangkanja itoe...(5) naroellohi al-moeqodatoellati taththolioe alal af'idah, tafsir: tempat mengantjoer kaoem oewang jaitoe api neraka...(6) innaha alaihim moe'coedatoen fi'amadin moemaddadah, tafsir: bahwasannja api neraka itoe menoetoep diatas mereka kaoem oewang jang jahat itoe..."." Kapitalisme bagi mereka juga dikalim sebagai bagian dari 'fitnah' yang menimbulkan kesengsaraan, kemelaratan dan kelaparan. Oleh karenanya,

7 Hadji Misbach, Islam dan Gerakan, dalam Medan Moeslimin 11 (1 Djoeni 1923). hlm 290.

$8 \quad$ M. Zaki Mubarak, Op. Cit., hlm 57.

9 Nasroedin, Qoer'an dan kapitalis-proletar, dalam medan moeslimin 10 (1924). hlm50-51. 
'fitnah' kapitalisme harus dihancurkan. Mereka mengajukan legitimasi hukum untuk menghancurkan 'fitnah' kapitalisme dari surat Al-Baqarah ayat 191-192 yang mereka interpretasikan sebagai berikut : “(1) waqootlhiloehoem hatta la takoena fitnah wa jakoenaddienoelillah, tafsir: lawanlah olihmoe sampai ta'ada fitnah (kapitalisme), begitoelah perintah agama (2) wa-l-fitnatoe asjaddoe mina'lqotl, tafsir: adanja fitnah kapitalisme itoe lebih berbahaja ditimbang dengan memboenoeh (3) fala'oedwana illa 'aladzoolimien, tafsir: tida ada seteroe jang besar melainkan si dzalim-dzalim (kapitalis) itoe". ${ }^{10}$ Kecaman juga mereka arahkan kepada siapapun yang memihak dan bersekutu dengan kaoem oewang. Hal ini berdasarkan hadits Nabi yang mereka tafsirkan sebagai berikut: "man tadlo'a lighanie li-adjli ghinaihi dzahaba stoeloestaa dienihi, artinya: Siapa-sipa orang jang mendjilat kepada kaoem oewang (capitalist) mendjilatnja itoe karena oewangnja, maka hilang doewa pertiga agamanja. ${ }^{11}$ Kecocokan demi kecocokan antara komunisme dan Islam, akhirnya mengantarkan H. Misbah sampai pada kesimpulan bahwa : “... Communist ada termasoek dalam tjita-tjita Islam, kaoem Islam jang sedjati haroes merasa wadjib mengoeatkan tjita-tjita dan sikapnja communisten tentang atoeran pergaoelan hidoep dalam doenia bersama". ${ }^{12}$

Selain 'berkenalan' dengan ajaran-ajaran Islam, Marxisme juga 'menyapa' alam pikir tradisi Jawa. Perselingkuhan Marxisme dan tradisi Jawa menemukan bentuknya dengan munculnya semboyan 'Sama RataSama Rasa' dan 'Bangkitnya Kaoem Kromo'. Jargon 'Sama Rata-Sama Rasa' dipopulerkan oleh Marco Kartodikromo ketika ia menulis syair yang dimuat dalam surat kabar Sinar Djawa pada tahun $1918 .{ }^{13}$ Semboyan ini mengingatkan kita pada gagasan Marx tentang 'masyarakat tanpa kelas' yang ditandai dengan penghapusan hak milik pribadi atas alat-alat produksi, penghapusan adanya kelas-kelas sosial, penghapusan pembagian

Medan Moeslimin 10 (1924). hlm 206.

Haroenrasjid, dalam Medan Moeslimin 10 (1924). hlm. 54.

H. Misbach, dalam Medan Moeslimin 9 (1923). hlm 291. Tentang pandanganpandangan H. Misbah seputar pergulatan wacana Islam, Marxisme, Komunisme, sosialisme dan perseteruannya dengan rival utamanya dari kelompok SI-Putih, HOS. Tjokroaminoto dan H. Agoes Salim, lihat Zainul Munasichin, Berebut Kiri, Pergulatan Marxisme Awal Di Indonesia 1912-1926, Yogyakarta:LKiS 2005. hlm. 115.

13 Marco Kartodikromo, Sama Rata dan Sama Rasa, dalam Sair Rempah-Rempah (Semarang:Druk N.V. Sinar Djawa, 1918). hlm. 1-5. 
kerja dan penguasaan alat-alat produksi yang dikelola dan dibagi secara bersama. ${ }^{14}$ Semboyan 'Sama Rata-Sama Rasa' selanjutnya menjadi simbol kebersamaan dan solidaritas pergerakan rakyat bumiputera.

'Bangkitnya Kaoem Kromo' merupakan idiom yang berhasrat untuk melebarkan makna 'kromo' yang semula bernuansa elitis menjadi populis. Istilah 'kromo' dalam terminologi Jawa lebih diartikan sebagai wujud kehalusan budi. Dalam masyarakat Jawa, dikenal bahasa Jawa Kromo. Bahasa ini sering dipakai oleh kalangan elite priyayi di lingkungan keraton. Sekaligus membedakan dengan bahasa Jawa yang digunakan masyarakat biasa, yakni bahasa Jawa 'Ngoko'. Para tokoh pergerakan yang sebelumnya sering melakukan kritik terhadap prilaku elite priyayi Jawa keraton berusaha menarik makna 'kromo' menjadi milik masyarakat umum. Semua orang berhak mengklaim dirinya sebagai kaum kromo, yang mengedepankan nilai-nilai kehalusan budi, suka menolong dan menjadi pahlawan terhadap kaum tertindas. ${ }^{15}$

Konsep Marxisme-Jawa semakin kokoh ketika Marco menerbitkan tulisan panjang, Babad Tanah Jawa pada Juni 1924. tulisan ini merupakan obsesinya sejak awal yang ingin menulis ulang sejarah tanah Jawa dengan menggunakan analisis sejarah -lebih tepatnya Materialisme Historis Marxisme-. Dalam pengantarnya, Marco menegaskan bahwa Babad Tanah Jawa yang ia tulis sama sekali berbeda dengan yang ditulis oleh para pujangga Jawa sebelumnya, seperti Prabu Jayabaya dan Ranggawarsita. Perbedaan itu terletak pada metode penulisan. Marco menulis dengan metodologi sejarah. Ia menggunakan periodisasi sejarah dan mendeskripsikannya dengan sistematis. Data sejarah yang diperolehnya disusun dalam bentuk narasi sejarah tanpa kiasan. Berbeda dengan para pendahulunya yang lebih banyak menulis dalam bentuk dongeng, tembang atau serat. Ia juga menganggap Babad Tanah Jawa yang sudah ada bersifat subyektif dan memihak kelompok tertentu. Salah satu kelompok yang ia maksud adalah kelompok yang memiliki 'oewang'. Pernyataan ini menegaskan cara pandang Marco terhadap sejarah

14 Franz Magnis-Suseno, Pemikiran Karl Marx, Dari Sosialisme Utopis ke Perselisihan Revisionisme, Jakarta:Gramedia, 1999. hlm 171.

15 Zainul Munasichin, Op. Cit,. hlm. 180. 
bangsanya atas dasar analisis Marxisme yang selalu mendeterminasi persoalan faktor produksi dalam gerak sejarah manusia, yaitu kapital. ${ }^{16}$

Dengan semangat yang hampir senada -dengan menggunakan analisis sejarah dan ekonomi-, Semaoen juga membuat periodisasi sejarah rakyat Jawa. Ia menyebutnya dengan istilah 'tiga kemadjoean'. Pertama, "djamannja Hindia diurus olih bangsa Hindia sendiri”. Kedua, "dioeroes bangsa Belanda dengan dibantoe olih radja-radja Djawa". Dan ketiga, "djamannja Hindia meniroe beberapa kepinteran dan pengetaoean serta kemadjoean Eropa”.

\section{Dari Kesadaran Teoritis Menuju Langkah Praksis}

Pada paruh terahir abad ke-19, saat liberalisme ekonomi bergemuruh di dunia Barat, sayup-sayup gaungnya mulai terdengar di Hindia Belanda. Investasi bagi kelompok-kelompok non-pemerintah mulai terbuka luas. Disusul kemudian dengan berdirinya pabrik-pabrik di kotakota. Migrasi dari desa ke kota semakin meningkat. Menjadi buruh di pabrik menjadi profesi baru, sebuah identitas lebih bergengsi dibanding buruh tani di pedesaan. Terjadi pergeseran luar biasa dalam sistem perekonomian masyarakat bumiputera, sistem agraris menjadi sistem industri, ditandai dengan berubahnya status petani bumiputera menjadi kaum buruh. Maka terjadilah industrialisasi dan proletarisasi di Hindia Belanda, ditandai dengan munculnya masyarakat buruh dalam struktur sosial masyarakat Hindia Belanda. Sebuah struktur sosial yang belum pernah dikenal dalam sejarah perubahan masyarakat sebelumnya. Kelompok buruh inilah yang kemudian menyita perhatian banyak pihak, baik kaum pergerakan, para pemilik modal (kaum kapitalis) maupun pemerintah. Tak pelak, hal ini memaksa para tokoh pergerakan untuk merumuskan kembali pola perlawanan menghadapi pemerintah dan kaum kapitalis.

Salah satu tokoh pergerakan yang sangat terobsesi untuk merumuskan pola baru tersebut adalah Semaoen, seorang pemimpin Sarekat Islam (SI) cabang Semarang, yang memiliki hubungan dekat dengan ISDV, organisasi kaum sosialis-marxis Belanda di Hindia Belanda, bahkan ia menjadi satu-satunya anggota pertama dari orang

16 Cerita selengkapnya tentang tulisan Marco lihat Zainul Munasichin, Op. Cit., hlm. 186. 
bumiputera. Semaoen memulai analisanya dari apa yang telah dicapai oleh para kapitalis, mereka mampu menjadi kekuatan dominan, bukan hanya terhadap bumiputera, tetapi juga berhasil mengendalikan kebijakan politik pemerintah. Kunci keberhasilan dominasi mereka, kata Semaoen, adalah pengorganisasian diri. Menurutnya, jika mengikuti proses yang sewajarnya -seperti yang diramalkan Karl Marx- dari perjalanan kapitalias, semestinya situasi kompetitif antarkapitalis di pasar bebas dapat menghancurkan mereka sendiri. Namun, ternyata itu bisa dihindari karena mereka menempuh jalan kompromi antar sesama mereka. ${ }^{17}$

Berangkat dari amatan-amatan tersebut, Semaoen berkeyakinan bahwa perjuangan masyarakat bumiputera bisa berhasil hanya jika mereka bersatu. Maksudnya mereka harus mengorganisasi diri dalam satu wadah organisasi seperti yang dilakukan oleh para kapitalis. Ini bisa tercapai hanya jika rakyat sadar akan keperluan mereka. Selama mereka belum sadar, semua usaha akan gagal. Satu-satunya cara yang harus ditempuh adalah dengan berbicara 'blak-blakan' dan jelas melalui artikel-artikel (persdelict), agar mudah dipahami oleh mereka. Tulisan-tulisan yang logis dan ilmiah tidak berarti apapun karena sulit dipahami oleh rakyat. Dalam situasi seperti ini yang diperlukan adalah orang-orang berani, bukan orang terdidik dan pandai, orang yang berani menunjukkan gigi, bukan 'lidah'. ${ }^{18}$

Selanjutnya Semaoen melihat ada tiga pilihan wadah perkumpulan bumiputera yang dapat dijadikan ujung tombak perjuangan rakyat. Yaitu, organisasi perdagangan (koperasi), organisasi politik (partai) dan organisasi buruh (vakbond). Namun, bagi Semaoen dua wadah perkumpulan yang pertama masih dianggap bermasalah. Koperasi dianggap terlalu lamban -meskipun dinilai sangat strategis untuk menciptakan kemandirian ekonomi bumiputera- untuk bisa diharapkan cepat menandingi kekuatan kapitalis yang semakin lama semakin meggurita. Sedangkan organisasi politik dinilai terlalu beresiko, karena sasaran utamanya adalah merebut kekuasaan atau menggulingkan kekuasaan. Dan untuk dapat mencapainya, diperlukan infrastruktur yang memadai, mulai dari kepemimpinan politik yang tangguh sampai kekuatan massa yang betul-betul militan dan tidak mudah patah. ${ }^{19}$ Akhirnya, pilihan jatuh pada wadah yang terakhir, organisasi buruh (vakbond), karena dinilai

17 Semaoen, Hikajat Kadiroen, Yogyakarta:Yayasan Bentang Budaya, 2000. hlm 116.

18 Sinar Djawa, 27 Oktober 1917.

19 Semaoen, Hikajat kadiroen, Yogyakarta:Yayasan Bentang Budaya, 2000. hlm 123. 
paling efektif dan beresiko lebih kecil. Kata Semaoen: "Mengingat beratnja djalan jang pertama, maka ada tjara lain jang harus didjalani oleh ra'jat dengan melalui djalan jang kedua, jaitu perkoempoelan pekerja bersatu dalam vakbond. Di sini para ra'jat mendjadi kaoem boeroeh bersatu dengan sesama boeroeh sesuai dengan pekerjaannja masingmasing ... Dengan bersatu dalam vakbond-vakbond itoe, kaoem boeroeh laloe bisa berkuasa meneroeskan djalannja pekerjaan ataoe proesahaan, joega bisa berkoeasa bersama-sama oentoek menghentikan djalannja peroesahaan“. ${ }^{20}$ Apa yang sedang digagas oleh Semaoen dengan menjadikan kaum buruh sebagai ujung tombak perjuangan rakyat Hindia Belanda melawan kapitalisme dan melakukan revolusi sosial, mengingatkan kita pada apa yang diprediksi oleh Karl Marx bahwa kelas pekerja (proletar) atau kaum buruh - the class of modern wage labourers who having no means of production of their own - adalah kelas yang akan memainkan peranan dalam perubahan sosial, yakni menggulingkan kelas kapitalis-borjuis. $^{21}$

Bersama kawan-kawan seperjuangannya di SI Semarang, Semaoen kemudian mengkampanyekan dan mempropagandakan apa yang menjadi kayakinannya. Sehingga pada kongres Centraal Sarekat Islam (CSI) di Surabaya pada September 1918, ia berhasil mendesak para peserta kongres untuk memutuskan mencantumkan pasal tentang penolakan terhadap kapitalisme dalam statuen CSI dan menyatakan SI sebagai organisasi pergerakan pertama di Hindia Belanda, yang secara eksplisit membela kepentingan buruh. Keputusan tersebut ditindaklanjuti dengan langkah pembentukan organisasi buruh secara massif di seluruh wilayah Hindia Belanda. Sampai Desember 1919, tidak kurang dari 44 organisasi serikat buruh didirikan dengan jumlah anggota mencapai 45.112 orang. ${ }^{22}$

20 Semaoen, Hikajat kadiroen, Yogyakarta:Yayasan Bentang Budaya, 2000. hlm 124.

21 Andi Muawiyah Ramly, Peta Pemikiran Karl Mark, Materialisme Dialektis dan Materialisme Historis, Yogyakarta:LKiS 2000. hlm 151.

22 Seperti dilaporkan oleh surat kabar Soeara Bekelai, Serikat Buruh Pabrik atau Personeel Fabriek Bond (PFB) menempati urutan teratas dalam jumlah massa, sebanyak 8.723 anggota. Disusul urutan kedua yang ditempati oleh organisasi serikat buruh kereta api (VSTP) dan Persatoean Goeroe Hindia Belanda (PGHB), masingmasing terdiri dari 6.000 anggota. Dan diurutan ketiga, Perserikatan Pegawai Pengadilan Boemiputera (PPPB) terdiri dari 4.000 anggota. Selain bersifat sektoral, sebagian perserikatan buruh juga mengorganisasi diri atas nama kedaerahan. Diantaranya adalah Kapem Boeroeh SI Semarang dengan anggota 1.400 orang. Kaoem Boereoh dan Tani Probolinggo (300 orang), Persatoean Kaoem Boeroeh dan 
Perjuangan Semaoen dan kawan-kawannya ternyata tidak berhenti sampai disini. Pada kongres Vakcentraale Buruh Desember 1919 di Yogyakarta, Semaoen, Darsono, Baars dan kawan-kawan mengajukan usulan agar dibentuk semacam komite sentral organisasi buruh yang bertugas mengkoordinasi dan menyatukan persepsi gerakan kaum buruh di seluruh Hindia Belanda. Dan usul mereka pun diterima. Namun, terjadi perdebatan sengit seputar nama komite sentral buruh tersebut. Semaoen dan kawan-kawan mengusulkan nama Revolutionnair Sosialistische Vakcentraale (RSV). Usulan ini ditolak mentah-mentah oleh kubu CSI yang diwakili oleh Tjokroaminoto, Agoes Salim, dan Soerjopranoto mereka inilah kelompok yang menamakan dirinya sebagai SI-Putih-, didukung oleh delegasi PGHB (Persatoean Goeroe Hindia Belanda), Dwidjosewojo dan Mohammad Zaen. Mereka meminta nama komite sentral buruh tidak menyebutkan istilah revolusioner. Bagi mereka istilah revolusioner dianggap terlalu menakutkan. Jika kata itu dipaksakan, organisasi buruh yang belum memahami sepenuhnya istilah tersebut akan berpikir ulang untuk bergabung dengan Vakcentraale. Mereka juga khawatir kata revolusioner itu akan menghambat proses perizinan pendirian Vakcentraale Buruh ketika diajukan kepada pemerintah. Istilah revolusioner bisa disalahartikan oleh pemerintah sebagai salah satu upaya untuk menyingkirkan pemerintah Hindia Belanda. Setelah melalui perdebatan yang cukup alot, kubu Semaoen akhirnya melunak, dan ia pun kemudian mengajukan nama Vakcentraale Buruh menjadi Persatoean Perkoempoelan Kaoem Boeroeh (PPKB). Dan akhirnya disepakati oleh peserta kongres. Meskipun gagasan revolusioner Semaoen kandas di arena kongres, secara politik, posisi Semaoen bisa dibilang menang. Terbukti, ia akhirnya terpilih secara aklamasi sebagai Ketua Umum PPKB. Dan secara de jure, ia adalah penguasa tertinggi dalam organisasi buruh Hindia. Dia berwenang untuk memutuskan kapan buruh Hindia harus bergerak atau menahan diri menghadapi represi para kapitalis. ${ }^{23}$

Tani (PKBT) Solo (800 orang), PKBT Klaten (150 orang) dan lain-lain. Lihat Zainul Munasichin, Op. Cit., hlm 95.

23 Zainul Munasichin, Op. Cit., hlm 99-103. 


\section{Partai itu Bernama PKI}

Pada saat kader-kader SI-Merah sedang bergiat meradikalisasi gerakan CSI ke arah praksis-revolusioner, mereka juga mulai memainkan peranan dalam organisasi 'induk' mereka, ISDV. Di mulai -antara tahun 1915-1917- dengan hengkangnya sejumlah tokoh 'Belanda' ISDV karena konflik internal $^{24}$ dan membanjirnya anggota SI menjadi anggota ISDV. Sehingga pada tahun 1918, ISDV praktis menjadi perkumpulan Indonesia walaupun Belanda-Belanda masih bertengger di pucuk pimpinan untuk memudahkan urusan dengan pihak penguasa. ${ }^{25}$

Pada bulan Oktober 1917, revolusi sosialis-komunis meletus di Rusia -populer dengan nama Revolusi Bolshevik- dan kaum buruh Rusia berhasil menumbangkan kekuasaan Tsar. Satu tahun berikutnya, Sociaal Democratische Arbeiders Partij (SDAP), sebuah Partai Buruh Sosial Demokrat Belanda -partai dimana tokoh sentral ISDV, Sneevliet, memulai karir politiknya- menyatakan dirinya sebagai Partai Komunis Belanda $(\mathrm{CPN})$. Kedua momentum inilah yang kemudian menyemangati para tokoh sosialis-komunis di Hindia Belanda untuk mempertegas identitasnya. Maka pada kongres ISDV ke-7, bulan Mei 1920, disepakati penggantian nama ISDV menjadi Perserikatan Komunis di Hindia. ${ }^{26}$

24 Konflik ini sudah dimulai sejak kongres pertama ISDV tahun 1915. Perselisihan terjadi antara Sneevliet dan Schoutman. Menurut Schoutman benih sosialisme belum saatnya ditebarkan di kalangan perkumpulan-perkumpulan di Hindia-Belanda. Jika disebarkan, malah akan mengakibatkan pemberontakan prematur yang akan merugikan gerakan sosialis sendiri, karena masyarakat Hindia-Belanda belum siap. Sneevliet dengan lantang membantah pandangan ini. Ia lantas mengajukan Semaoen satu-satunya orang Indonesia di dalam kongres- untuk menanggapi pandangan itu. Semaoen dengan tegas mengatakan bahwa orang Indonesia sudah sadar karena meraka membayar pajak dan mereka selalu bertanya untuk apa membayar pajak. Dan ia menambahkan bahwa jika Indonesia sudah berontak, itu artinya 'mereka sudah siap'. Akibat dari perseteruan ini, sebagian besar anggota ISDV yang tidak sejalan dengan Sneevliet memilih hengkang dari ISDV dan pada tanggal 8 September 1917, mereka membentuk SDAP cabang Hindia-Belanda dengan nama Indische Sociaal Democratische Partij (ISDP). Lihat Soe Hok Gie, Op. Cit., hlm 68 dan Marwati Djoened Poesponegoro dan Nugroho Notosusanto, Sejarah Nasional Indonesia V, Jakarta:Balai Pustaka, 1993. hlm 200.

25 Soe Hok Gie, Op. Cit., hlm 69.

26 Usul penggantian nama ini berawal ketika ISDV menerima surat Haring (nama samaran Sneevliet) dari Shanghai (Canton), pada awal 1920, yang menganjurkan agar ISDV menjadi anggota Komintern (Komunis Internasional). Untuk itu, harus dipenuhi 21 syarat, diantaranya memakai nama jelas partai komunis dan menyebut nama negaranya. Semaoen lalu mengirimkan tembusan surat ini kepada tokoh-tokoh ISDV, termasuk Darsono yang waktu itu masih berada dipenjara Surabaya. Dalam suatu 
Sebelum kesepakatan diambil, kongres berlangsung panas. Ketegangan disulut oleh usul Semaoen, Bergsma dan Baars untuk merubah nama ISDV, dengan alasan untuk membedakan diri dengan 'kaum sosialis palsu' dan untuk mengidentifikasikan diri dengan Komintern. ${ }^{27}$ Hal ini ditentang habis oleh Hertog -yang pada waktu itu menjadi pimpinan ISDV- dan Alimin. Alasannya, jika menerima perintah Komintern, berarti di bawah Rusia. Walaupun ISDV mendukung revolusi Bolsevik di Rusia, tetapi tidak semua 'paket' komunisme cocok dengan kondisi sosial-politik di Indonesia, seperti sistem diktator proletar dan sistem Soviyet yang notabene merupakan program komunis yang paling krusial. Semaoen berusaha meyakinkan bahwa komintern bukan milik Rusia dan perubahan nama sekedar disiplin organisasi. Untuk menentukan keputusan akhirnya dilakukan voting. Hasilnya, ternyata hanya cabang Surabaya, Bandung dan Ternate yang menolak perubahan nama ISDV. Disepakatilah perubahan nama ISDV menjadi Perserikatan Komunis di Hindia (PKH) dan Semaoen terpilih sebagai ketua. Pada Desember tahun yang sama PKH berganti nama menjadi Partai Komunis Indonesia (PKI). Proses penggantian nama ini merupakan upaya pengindonesiaan gerakan Marxisme -lebih tepatnya komunisme-sosialisme- ${ }^{28}$

\section{Memilih Jalan Revolusi}

Di bawah komando PPKB pimpinan Semaoen, aksi-aksi buruh semakin gencar dilakukan antara tahun 1920-1922. Pada 1920, PFB melakukan pemogokan buruh yang dipicu oleh penolakan pihak majikan untuk mengakui PFB sebagai organisasi yang mewakili anggotanya. Di Surabaya pada 15 November 1920 terjadi pemogokan buruh yang

pertemuan dengan Hertog (saat itu menjadi ketua ISDV) di penjara Surabaya, Darsono menyatakan persetujuannya sembari menambahkan dua alasan lagi :

1. Manifest yang ditulis Marx-Engels dinamai Manifest Komunis dan bukannya Manifest Sosial Demokrat.

2. Rakyat Indonesia tidak dapat membedakan antara ISDV yang revolusioner dan ISDP yang evolusioner. Lihat Soe Hok Gie, Op. Cit., hlm 69-70.

27 Soal usulan keterkaitan gerakan sosialis (gerakan buruh) di Hindia dengan gerakan buruh di seluruh dunia di bawah komando kaum Bholsevik Rusia, juga pernah disampaikan oleh Semaoen pada kongres Vakcentraale Buruh Desember 1919 yang mengagendakan pembentukan Persatoean Perkoempoelan Kaoem Boeroeh (PPKB). Namun usulan Semaoen ditolak dan kandas di arena kongres.

28 Proses penggantian nama dan pendirian PKI - menurut Soe Hok Gie- tidak pernah dilansir dan dibahas dalam Sinar Hindia, namun ia peroleh dari hasil wawancara dengan Semaoen pada 5 September 1964. Lihat Soe Hok Gie, Op. Cit., hlm 95. 
melibatkan sekitar 800 buruh pada Droogdok Maatschappij. Selama 1920, tercatat pemogokan buruh di 72 pabrik gula. Pemogokan ini melibatkan sekitar 25.000 buruh di seluruh pulau Jawa mulai Yogyakarta, Semarang, Solo, Madiun, Pasuruan, Probolinggo dan sebagainya. Pada Agustus 1921 pemogokan terjadi di lingkungan buruh pelabuhan Surabaya. Dan pada Januari 1922, giliran pegawai pegadaian (PPPB) melakukan aksinya yang melibatkan 79 rumah gadai dengan sekitar 8.500 buruh. Pada tahun yang sama, PFB -mengatasnamakan PPKB- kembali melakukan aksi mogok. Pemogokan kali ini melibatkan jumlah massa yang jauh lebih besar dari sebelumnya, yang meliputi wilayah Yogyakarta, Cirebon, Pekalongan, Kedu, Semarang, Rembang, Kediri, Surabaya dan Pasuruan. ${ }^{29}$ Maraknya aksi-aksi mogok buruh, tentu saja membuat 'gerah' pemerintah Hindia Belanda. Mereka tidak segan-segan mengerahkan aparat keamanan untuk membubarkan aksi-aksi buruh. Segera setelah aksi-aksi mogok itu usai, pemerintah mencabut izin rapat umum (vergadering). Atas nama rust en orde, pemerintah melakukan pengawasan ketat terhadap setiap pertemuan yang dilakukan para tokoh pergerakan. Sejak saat itu, aktivitas pergerakan bumiputera dapat dikatakan tiarap.

Pada masa cooling down, CSI mengambil langkah yang cukup mengagetkan tokoh-tokoh pergerakan bumiputera. Pada kongresnya di Madiun tahun 1923, CSI memutuskan melarang semua kader SI merangkap anggota di organisasi pergerakan lainnya, terutama PKI. ${ }^{30}$ Para kader SI yang sebelumnya masuk dalam gerbong SI Merah memilih hengkang dari SI. Sebagian bergabung dengan PKI dan sebagian yang lain memilih mendirikan organisasi baru meskipun tetap menjalin relasi dengan PKI. Para 'alumni' SI Merah selanjutnya membentuk organisasi baru bernama Sarekat Rakyat (SR) yang digawangi Ali Archam. Tidak lama setelah melakukan pembersihan dari anasir SI Merah, SI merubah penampilannya menjadi organisasi keagamaan dan tidak lagi aktif melakukan pengorganisasian buruh. SI kembali menjadi organisasi 'ayam sayur'. Dengan demikian kepemimpinan politik di Hindia mutlak berada di tangan PKI dan kesempatan ini tidak disia-siakan oleh PKI. Melalui

29 Soegiri DS. dan Edi Cahyono, Op. Cit., hlm 119.

30 Keputusan 'emosional' ini dipicu oleh kegagalan aksi pemogokan PFB -yang notabene sayap buruh CSI, karena tidak mendapat dukungan dari para petinggi PPKB -yang juga tokoh SI Merah dan pimpinan PKI-. CSI menyimpulkan bahwa para kader SI yang merangkap anggota PKI tidak lagi dapat diajak bekerja sama. 
organnya (VSTP), pada Mei 1923, PKI melancarkan aksi mogok besarbesaran di seluruh Jawa. Namun sayang, seperti aksi-aksi sebelumnya, aksi ini juga dapat diantisipasi dan dipatahkan oleh pemerintah. Bahkan harga yang harus dibayar dari aksi inipun cukup mahal, Semaoen dan $\mathrm{H}$. Misbah ditangkap dan ditendang keluar dari Hindia Belanda.

Pembuangan Semaoen dan H. Misbah tidak menyurutkan semangat 'botjah-botjah kiri' untuk melakukan aksi. Perlawanan mereka bahkan justeru semakin radikal. Aksi mereka tidak lagi cukup dengan aksi mogok dan boikot, melainkan sudah menjurus pada aksi-aksi anarkis. Mereka melakukan aksi teror dan sabotase dengan menggulingkan kereta api, meledakkan bom ke arah lokomotif dan menghancurkan rel-rel. Aksi kekerasan yang digelar massa PKI selama 1923, memaksa para pemimpin PKI untuk segera mengambil langkah-langkah taktis, bagaimana radikalisasi massa yang semakin meningkat tidak malah merugikan gerakan PKI dan sekaligus dijadikan senjata pamungkas untuk melakukan revolusi sosial. Akhirnya, pada kongres PKI di Batavia pada 1924, para tokoh PKI benar-benar merasakan bahwa detik-detik revolusi sosialis itu akan segera tiba. Mereka pun mulai menyiapkan infrastruktur revolusi dengan memobiliosasi basis massa PKI dan mengkonsolidasi organ-organ yang berada di bawahnya. Puncak kebulatan tekad untuk melakukan revolusi diputuskan di Candi Prambanan pada 15-25 Desember 1925. Sebetulnya para pemimpin PKI merencanakan pertemuan serentak dengan organisasi radikal lainnya di Solo sepuluh hari sebelumnya. Namun pertemuan tersebut dibubarkan pemerintah karena tidak mangantongi izin. Padahal saat itu tidak kurang dari 20.000 simpatisan PKI sudah hadir di Solo. Dari Solo, mereka menuju Candi Prambanan. Tepat pada 25 Desember 1925, PKI memutuskan untuk melakukan revolusi merebut kekuasaan dari pemerintah Hindia Belanda. ${ }^{31}$ Genderang revolusi mulai ditabuh setahun berikutnya, November 1926, serentak di beberapa titik utama, Jakarta, Banten, Bandung, Surakarta dan Kediri. Sedangkan di Silungkang, Sumatera Barat, aksi baru dimulai pada Januari 1927.

Inilah puncak perlawanan kaum bumiputera terhadap kekuasaan dan penindasan 'kaoem oewang' dan pemerintah Hindia Belanda yang berpihak kepada mereka dengan menempuh jalan revolusi terbesar pertama dalam sejarah Hindia Belanda (Indonesia). Sangat disayangkan

31 Zainul Munasichin, Op. Cit., hlm 113. 
memang kalau ternyata aksi spektakuler ini berakhir tragis. Ribuan nyawa terenggut dan ratusan lainnya harus merasakan pahitnya hidup dibalik terali besi. Dan yang paling telak, PKI dan seluruh aktivitas radikal 'botjah-botjah Marxis' divonis sebagai organisasi dan kegiatan terlarang. Terlepas dari kenyataan bahwa gerakan tersebut menuai kegagalan, yang jelas adalah bahwa Semaoen, Darsono, H. Misbah dan tokoh PKI lainnya telah berusaha menerjemahkan pembacaan mereka atas apa yang mereka yakini sebagai kebenaran dari ajaran Marxisme dan mewujudkannya dalam gerakan konkret. Bahwa perjuangan demi menegakkan martabat kemanusiaan dari ketertindasan kuasa uang, perubahan peri kehidupan manusia ke arah yang lebih manusiawi dan perlawanan terhadap seluruh aparatus 'kapitalisme', harus dilakukan, meskipun nyawa sebagai taruhannya. "Mengorbankan njawa", demikian petuah H. Misbah, "boekan apa-apa". Perjuangan melalui konfrontasi 'berdarah' yang dilakukan Semaoen dan kawan-kawan boleh jadi berakhir seiring kegagalan revolusi 1926, namun mereka yakin bahwa 'hantu-hantu Marx' akan tetap selalu menitis sepanjang sejarah manusia selama penindasan dan kesewenang-wenangan yang dilakukan oleh manusia atas manusia lainnya masih terus berlangsung di atas muka bumi.

\section{DAFTAR PUSTAKA}

Botjah Goenoengkidoel, Rasa Kemanoesiaan Haroes Hidoep pada kita, dalam Doenia Baroe, Rebo, 11 Djoeli 1923.

Gie, Soe Hok, 2005, Di Bawah Lentera Merah, Riwayat Sarekat Islam Semarang 1917-1920, Yogyakarta: Bentang.

Haroenrasjid, dalam Medan Moeslimin 10, tahun 1924, halaman 54.

Kartodikromo, Marco, 1981, Sama Rata dan Sama Rasa, dalam Sair Rempah-Rempah, Semarang: Druk N.V. Sinar Djawa.

Koch, 1951, Menudju Kemerdekaan, Djakarta: Dj. Pembangunan.

McVey, Ruth T, 1965 The Rise of Indonesian Communism, Ithaca-NY: Cornell.

Medan Moeslimin 9, tahun 1923, halaman 275.

Medan Moeslimin 10, tahun 1924, halaman 205.

Medan Moeslimin 10, tahun 1924, halaman 206.

Misbach, Hadji, Islam dan Gerakan, dalam Medan Moeslimin 11, 1 Djoeni 1923, halaman 290. 

, dalam Medan Moeslimin 9, tahun 1923, halaman 291.

Mubarak, M. Zaki, "Marxisme-Religius, Pemikiran dan Revolusi dalam SI-Merah Solo”, Jurnal Gerbang edisi 02 tahun II April-Juni 1999.

Munasichin, Zainul, 2005, Berebut Kiri, Pergulatan Marxisme Awal Di Indonesia 1912-1926, Yogyakarta: LKiS.

Nasroedin, Qoer'an dan kapitalis-proletar, dalam Medan Moeslimin 10, tahun 1924, halaman 50-51.

Poesponegoro, Marwati Djoened dan Nugroho Notosusanto, 1993, Sejarah Nasional Indonesia V, Jakarta: Balai Pustaka.

Ramly, Andi Muawiyah, 2000, Peta Pemikiran Karl Mark, Materialisme Dialektis dan Materialisme Historis, Yogyakarta: LKiS.

Semaoen, 2000, Hikajat Kadiroen, Yogyakarta: Yayasan Bentang Budaya. Sinar Djawa, 27 Oktober 1917.

Soegiri dan Edi Cahyono, 2003, Gerakan Serikat Buruh, Jaman Kolonial Hindia Belanda Hingga Orde Baru, Jakarta: Hasta Mitra.

Suseno, Franz Magnis, 1999, Pemikiran Karl Marx, Dari Sosialisme Utopis ke Perselisihan Revisionisme, Jakarta: Gramedia. 